\section{Calibration Tile Slightly Influences Assessment of Color Change in Pears from Green to Yellow Using the L, a, b Space}

\author{
Christian Chervin \\ CSIRO, Division of Horticulture, Institute for Horticultural Development, \\ Private Bag 15, South East Mail Centre, Vic 3176, Australia \\ Peter Franz and Fiona Birrell \\ Agriculture Victoria, Institute for Horticultural Development, Private Bag 15, \\ South East Mail Centre, Vic 3176, Australia
}

Additional index words. Pyrus, CIELAB, hue, chroma, value, senescence, ripening

Color change from green to yellow is common in many ripening fruit and in senescing processes of chlorophyllous organs.

As part of a study on pear ripening (Pyrus communis L. cv. Packham's Triumph), we were looking for a method to describe the color change of the fruit skin. In the last 20 years, color changes have been quantified frequently in the L, a, b color space. Recently, McGuire (1992) summarized uses of the L, a, b scale in objective color measurement, highlighting the benefits of using polar coordinates in the $a, b$ plane: hue angle (angle from the $+a$ axis to the ray from the origin to the $a, b$ point anti-clockwise) and chroma (distance from origin to the $\mathrm{a}, \mathrm{b}$ point). In agreement with this author, Gnanasekharan et al. (1992) reported some positive correlations between hue angle variations of yellowing vegetables and sensory evaluation of the color.

Our survey of the last decade's publications on the yellowing of fruit and vegetative organs revealed that a range of color parameters were presented. These included: $a$ or $b$ values alone, $a / b$ or $(L \times a) / b$ ratios, hue angle or chroma. The use of three distinct calibration tiles was reported: pale green $(\mathrm{L}=66.2, \mathrm{a}=$ $-15.69, \mathrm{~b}=8.44)$, yellow $(\mathrm{L}=85, \mathrm{a}=-2.0, \mathrm{~b}$ = 23.8), and white $(\mathrm{L}=97.9, \mathrm{a}=-0.49, \mathrm{~b}=$ 1.91), while some authors did not specify which tile they had used.

The aim of the present work was to investigate whether or not these three calibration tiles would produce any significant differences in the values L, a, b, hue, and chroma. The results will provide information about their use in experiments and the possibility of comparing various authors' results. They may also be of some importance when examining color measurements used for quality control.

Green pears were harvested from an orchard on 11 days during the first 2 weeks of Mar. 1995. Color readings of the fruit were performed with a Minolta CR200 chromameter

Received for publication 18 Sept. 1995. Accepted for publication $27 \mathrm{Feb} .1996$. The cost of publishing this paper was defrayed in part by the payment of page charges. Under postal regulations, this paper therefore must be hereby marked advertisement solely to indicate this fact.

(Minolta, Osaka, Japan), equipped with an 8$\mathrm{mm}$ measuring head and a $\mathrm{C}$ illuminant (6774K). On each harvest day (block), the color was measured on one cheek of six pears (green pears) after calibration with each of the three tiles. All pears then were stored for 1 month at $0 \mathrm{C}$ and then allowed to ripen for 8 days at 20C. Color of these yellow pears was measured again using the same protocol. There were only 10 blocks of six pears left, as one block was lost due to temperature mismanagement. Hue angle and chroma were calculated using the raw data, then the six fruit values of each block were averaged for all color parameters, as individual fruit were not identified. The formulae used to transform color results were chroma $=\left(\mathrm{a}^{2}+\mathrm{b}^{2}\right)^{1 / 2}$ and hue angle $\left(^{\circ}\right)=$ $180+\tan ^{-1}(\mathrm{~b} / \mathrm{a})$, as a $<0$. We also calculated the Euclidean norm or "Value," $|\mathrm{E}|=\left(\mathrm{L}^{2}+\mathrm{a}^{2}\right.$ $\left.+b^{2}\right)^{1 / 2}$, because it is sometimes used in the literature. SAS's analysis of variance (ANOVA) (version 6.08, SAS Institute, Cary, N.C.) was used to compare the three tiles (green, yellow, and white), allowing for 11 (green pears) or 10 blocks (yellow pears). Tukey's HSD test of the three tiles were performed using the residual variance from ANOVA as the variance estimate.

During the ripening, the mean hue angle for all three tiles changed from $112.1 \pm 0.08$ (SE) for green pears to $98.0 \pm 0.13$ for yellow pears. The mean chroma changed only from $44.5 \pm 0.11$ for green pears to $44.8 \pm 0.10$ for yellow pears. This result confirms that hue angle is a good indicator of color change in the $\mathrm{a}, \mathrm{b}$ plane during yellowing; also, this result is logical as color varies around the chromatic
Table 1. Influence of the calibration tile on color parameters.

\begin{tabular}{|c|c|c|c|c|c|c|}
\hline \multirow{2}{*}{$\begin{array}{l}\text { Calibration } \\
\text { tile }\end{array}$} & \multicolumn{6}{|c|}{ Parameters $^{\mathrm{z}}$} \\
\hline & $\mathrm{L}$ & $\mathrm{a}$ & $\mathrm{b}$ & Hue angle $\left({ }^{\circ}\right)$ & Chroma & Value \\
\hline \multicolumn{7}{|c|}{ Green pears $^{y}$} \\
\hline Green & $64.01 \mathrm{~b}$ & $-17.24 \mathrm{~b}$ & $41.35 \mathrm{ab}$ & $112.67 \mathrm{a}$ & $44.81 \mathrm{a}$ & $78.05 \mathrm{ab}$ \\
\hline Yellow & $64.40 \mathrm{ab}$ & $-16.02 \mathrm{a}$ & $40.86 \mathrm{~b}$ & $111.43 \mathrm{~b}$ & $43.90 \mathrm{~b}$ & $77.91 \mathrm{~b}$ \\
\hline White & $64.59 \mathrm{a}$ & $-16.97 \mathrm{~b}$ & $41.61 \mathrm{a}$ & $112.20 \mathrm{a}$ & $44.95 \mathrm{a}$ & $78.70 \mathrm{a}$ \\
\hline \multicolumn{7}{|c|}{ Yellow pears ${ }^{y}$} \\
\hline Green & $72.84 \mathrm{a}$ & $-6.72 b$ & $44.48 \mathrm{a}$ & $98.60 \mathrm{a}$ & $45.03 \mathrm{a}$ & $85.66 \mathrm{ab}$ \\
\hline Yellow & $72.62 \mathrm{a}$ & $-5.40 \mathrm{a}$ & $43.29 b$ & $97.08 \mathrm{~b}$ & $43.68 \mathrm{~b}$ & $84.78 \mathrm{~b}$ \\
\hline White & $72.99 \mathrm{a}$ & $-6.53 b$ & $45.10 \mathrm{a}$ & $98.25 \mathrm{a}$ & $45.60 \mathrm{a}$ & $86.09 \mathrm{a}$ \\
\hline
\end{tabular}

${ }^{2}$ Numbers are means of six-pear samples $\times \mathrm{n}$ replications, $\mathrm{n}=11$ for green and 10 for yellow pears.

${ }^{y}$ Within columns, numbers followed by the same letter are not significantly different, using Tukey's HSD $(P \geq 0.05)$.

circle. Chroma, representing color saturation, only varied slightly during yellowing. However, during the senescence of other tissues [e.g., broccoli (Brassica oleracea L.) or spinach (Spinacia oleracea L.)], chroma did change (Gnanasekharan et al., 1992). The L values increased during yellowing (Table 1); according to the chromameter manual, this change may slightly influence the color tone in combination with chroma (from vivid to bright).

The yellow tile induced significantly lower values in magnitude than the use of white tile for all parameters except $\mathrm{L}$ on green pears (Table 1). The yellow tile induced significantly lower values than the use of green tile on green pears for all parameters, except " $b$ ", $\mathrm{L}$ and Value (Table 1). In the case of "a", for example, there was a difference of $\approx 1.25$ units between readings obtained after green and yellow calibrations, for green and yellow pears. These results represent a variation close to $12 \%$ of the total change of "a" during the yellowing from an average for all three tiles of $-16.7 \pm 0.08$ to $-6.2 \pm 0.10$.

When using the total color difference, $\Delta \mathrm{E}$ $=\left(\Delta \mathrm{L}^{2}+\Delta \mathrm{a}^{2}+\Delta \mathrm{b}^{2}\right)^{1 / 2}$ tg to compare the influence of the calibration tiles, yellow vs. green, white vs. yellow, and green vs. white gave $\Delta \mathrm{E}=1.37$, 1.22 , and 0.69 , respectively, for green pears and $\Delta \mathrm{E}=1.79,2.16$, and 0.66 , respectively, for yellow pears. These results emphasize that green and white tiles generated results that were closer to each other than to the yellow tile.

Choice of calibration tile has been highlighted rarely in previous papers. One may be tempted to use the calibration tile which is closest to the color being measured. In an experiment where the product undergoes yellowing, our data suggest that one calibration tile should be used for measuring all experimental units at each examination. If this is not done, then the variation in values produced by differing calibration tiles could be confounded with treatment. Our results should encourage researchers to take care when selecting the calibration tile to be used, and to cite it when reporting the results. Small differences in color may lead to acceptance or rejection of a great quantity of fruit during delivery checking or sorting with automated color determination.

\section{Literature Cited}

Gnanasekharan, V., Shewfelt, R.L., and M.S. Chinnan. 1992. Detection of color changes in green vegetables. J. Food Sci. 57:149-154.

McGuire, R.G. 1992. Reporting of objective color measurements. HortScience 27:1254-1255. 